\title{
Optimizing Roof Insulation for Roofs with High Albedo Coating and Radiant Barriers in India
}

Rathish Sathyabama Arumugam ${ }^{1}$, Vishal Garg ${ }^{2}$, Vinayaka Ram ${ }^{1}$, Aviruch Bhatia ${ }^{2}$,

1. Birla Institute of Technology \& Science - Pilani, Hyderabad Campus, Hyderabad, India.

2. International Institute of Information Technology - Hyderabad, Hyderabad, India.

\begin{abstract}
To make roofs energy efficient, typically two types of techniques are followed: Surface treatments (Cool Roofs, Radiant Barriers) and Thermal property modifications (Roof insulation). The interplay between these two techniques has been studied using energy simulations. A single storey, daytime operational, office building of $200 \mathrm{~m}^{2}$ area has been simulated for five climatic zones in India. A total of 88 different roof combinations have been studied for each climatic zone. An economic analysis using Internal Rate of Return has been performed to identify a suitable roof insulation thickness for a roof with high albedo, and radiant barrier combination. The incremental benefits in energy savings reduces by adding insulation after a limit. For a roof with Albedo of 0.6 and Radiant Barrier emittance of 0.2, the optimized roof R-value is $0.49 \mathrm{~m}^{2} \mathrm{~K} / \mathrm{W}$ in Hot \& Dry and Composite climates, 0.31 $\mathrm{m}^{2} \mathrm{~K} / \mathrm{W}$ in Warm \& Humid and Temperate climates, and $1.02 \mathrm{~m}^{2} \mathrm{~K} / \mathrm{W}$ for cold climates.
\end{abstract}

Key Words: Radiant Barriers, Cool Roofs, Insulation thickness optimization, Energy Simulation, Internal Rate of Return 


\section{Nomenclature}

$\begin{array}{ll}\text { ACH } & - \text { Air Changes per Hour } \\ \text { CDD } & - \text { Cooling Degree Days } \\ \text { CoP } & - \text { Coefficient of Performance } \\ \text { CRRC } & - \text { Cool Roof Rating Council } \\ \text { HDD } & - \text { Heating Degree Days } \\ \text { HVAC } & - \text { Heating Ventilation and Air Conditioning } \\ \text { IRR } & - \text { Internal Rate of Return } \\ \text { MARR } & - \text { Minimal Attractive Rate of Return } \\ \text { PTAC } & - \text { Packed Terminal Air Conditioning System } \\ \text { R Value } & - \text { Thermal Resistance } \\ \text { SR } & - \text { Solar Reflectivity }\end{array}$

\section{Introduction}

India is a tropical country with an average annual solar insolation between $4000-7000$ $\mathrm{Wh} / \mathrm{m}^{2}$-day [1]. This leads to high outdoor dry bulb temperature and higher cooling energy consumption in daytime operational buildings. Therefore, building envelope plays a very important role in reducing the cooling energy consumption of a building. Among various envelope components, roofs receive the maximum direct solar radiation [2]. So it is important to have an efficient roof to reduce the energy consumption of a building.

Figure 1: Heat transfer in a roof

Figure 1 shows the heat transfer in a roof. Part of the solar radiation reaching the roof surface is absorbed and the rest is reflected back. Part of the absorbed solar radiation is re-radiated back to the atmosphere, part of it is conducted in to the building and a part of it is lost in convection to the atmosphere. The heat reaching the inner surface is distributed by convection and radiation.

There are three solutions to reduce the heat transfer into the building. They are roof insulation, cool roofs, and radiant barriers. Though roof insulation is common in India, cool roofs and radiant barriers are relatively new solutions. Cool Roof Rating Council (CRRC) defines Cool Roofs as "any roof that reflects and emits the sun's heat back to the sky instead of transferring it into the building below" [3]. Radiant Barriers is a way of increasing the thermal performance of a roof by introducing a new layer with low emissivity below the roof 
surface [4]. The materials that are used as radiant barriers are characterized by a far infrared emittance of 0.1 or less [5]. Far infrared is a region in the infrared spectrum of electromagnetic radiation defined as any radiation with a wavelength of 15 micrometers $(\mu \mathrm{m})$ to $100 \mu \mathrm{m}$.

Many studies have been performed world-wide to understand the benefits of these three solutions. Various studies have highlighted the benefits of roof insulation $[6,7,8,9]$. Some of the note-worthy findings indicate that insulation can lead to increase in energy consumption under certain circumstances. D'Orazio et al. [6], states that over use of insulation can result in adverse effects. In their study conducted for a Mediterranean climate (Italy), it was found that over use of insulation reduces the effectiveness of traditional passive strategies and reduces indoor thermal comfort. Further, it leads to "box effect" in which the solar radiation entering the building through transparent surfaces becomes the heat sources inside the building during nights.

Halwaura $\mathrm{R}$ et al. [7] shows that insulated roof slabs could have a desirable behaviour with respect to life cycle performance in addition to providing other benefits such as cyclone resistance and higher robustness to the building.

Another simulation study by Masoso et al.,[8] on wall insulation for a building in Botswana concluded that insulation is not always suitable to reduce the cooling energy of a building. There exists a point for a given set of cooling set points, internal gains, when the building switches from "lower the u-value the better" to "higher the u-value the better". This is known as the "point of thermal inflexion".

It is possible that the combined use of Cool Roofs, Radiant Barriers, and Roof insulation can lead to an early occurrence of the point of thermal inflexion. Therefore, it is necessary to perform a combined analysis to find the optimal combination of cool roof, insulation, and Radiant Barriers.

Akhbari et al. [10] have studied the effect of roof reflectivity on different roof insulations for residential buildings. A parametric simulation for four different duct insulations, five different ceiling insulations, and four different levels of roof reflectivity over 32 different climatic regions was performed. The results show that for hot climates, increasing the roof reflectivity from $20 \%$ to $60 \%$ is worth over half of the roof insulation that is required for $20 \%$ reflectivity. 
Another study by Akbari et al. [11] for commercial buildings was performed to find adjustment factors for roofs with high reflectivity to reduce the insulation levels. These adjustment factors were computed in a way that the net energy use of the building remains constant when compared with the energy use of a dark-colored roof with insulation. Simulations were performed over DOE-2 prototype buildings over 19 different climate bins. The roof reflectivity varied from $5 \%$ to $75 \%$ with three different insulation levels.

Gentle et al. [12] studied the 18 different combinations or roof reflectivity and R-value of the roof over a temperate climate. The analysis focused on cooling months over the total cooling energy consumption and the peak energy consumption. The results show that moderately $\mathrm{R}$ value of $1.63 \mathrm{~m}^{2} \mathrm{~K} / \mathrm{W}$ is superior to high $\mathrm{R}$ value unless a roof is dark or the winter heating demand is high.

Though various studies have pointed out that highly reflective roofs have a lesser insulation requirement, the effect of Radiant barrier and cool roof on insulation is studied for Indian climatic zones. In this study, different combinations of Cool Roof, Radiant Barriers, and Roof insulation have been analysed for five different climatic zones of India as described in the National Building Code of India [13].

\section{Methodology}

\subsection{Simulation Model}

EnergyPlus V7.1 was used to create a model of an office building for this study. The model is a single storey building with core plus perimeter zones. The total roof area is $200 \mathrm{~m}^{2}$. The schedules are used as per a typical daytime operational building. The model has a window to wall ratio of $30 \%$ and a floor to ceiling height of $3.5 \mathrm{~m}$. Windows are equally distributed across all four walls. The materials and the internal loads taken in the model are as per Energy Conservation Building Code of India (Bureau of Energy Efficiency, 2007).The building is completely air conditioned with an air infiltration rate of $0.1 \mathrm{ACH}$ in the core zone and $0.2 \mathrm{ACH}$ in the perimeter zone. The air conditioning system taken in the building is a Packaged Terminal Air Conditioning System with a cooling CoP of 3.0 and electrical heating with a CoP of 1.0. Details of the model and the schedules are given in Table $1 \& 2$.

Figure 2: Schematic of the model considered for the simulation study 


\subsection{Variations for Parametric Analysis}

The parametric simulation was carried out for different roof insulation levels, cool roof reflectivity, and thermal emittance of Radiant Barriers. The insulation considered here is an over deck insulation, which has thermal properties similar to commercially available Styrofoam. The thermal conductivity of the insulation is $0.028 \mathrm{~W} / \mathrm{m} \mathrm{K}$. The insulation thickness has been varied from $0 \mathrm{~mm}$ to $50 \mathrm{~mm}$. Cool Roof has been characterized by roof reflectivity. The reflectivity has been varied from $20 \%$ to $90 \%$ with an increment of $10 \%$ per case. Radiant Barrier considered in this analysis has an aged thermal emittance of 0.2. This combination gives a total of 88 distinctive cases for the simulation study. The material properties considered have been summarized in Table 3. One city has been selected from each climatic zone of India. The details of the cities are given in table 4.

Table 3: Roof material properties

Table 4: Cities chosen for simulation study

\subsection{Economic Analysis}

The modern investment analysis states that any investment should be operated at a point where the marginal investment equals the marginal revenue. This means that the investment is acceptable as long as the rate of return on investment at least equals the cost of investable fund [14]. Internal Rate of Return (IRR), a very common decision making technique is the rate which equates the present value of a projected stream of cash flow with any positive initial cash investment.

$$
0=\sum_{t=1}^{n} \frac{C F_{t}}{(1+k)^{t}}+C O
$$

Where

" $\mathrm{CF}_{\mathrm{t}}$ " is the cash inflow in a year " $\mathrm{t}$ ",

" $n$ " is the number of years the IRR is computed,

" $\mathrm{k}$ " is the Internal Rate of Return, 
"CO" is the initial cash outlay.

In case of incremental insulation, the incremental energy savings has been observed to be diminishing. For a given roof reflectivity and Radiant Barrier system, IRR has been computed for every incremental $5 \mathrm{~mm}$ of insulation. Since the primary energy source is electricity, the energy savings has been directly correlated with electricity cost. The cost of electricity has been taken as INR 6 per kWh [15]. The future cost of electricity has been adjusted at an inflation rate of 5\% per year. Cost of insulation has been considered to be INR $8000 / \mathrm{m}^{3}$ (as per the current market process and as quoted by vendors). Since the life of insulation has been taken as 25 years (as per the information provided by the suppliers), the IRR analysis has also been performed for a period of 25 years.

Since IRR gives us an idea of the rate of return of the investment, this has been compared with MARR, fixed by Government of India (currently at 11.5\%). The rate of return has been benchmarked with a rate of $11.5 \%$ [16].

\section{Results and Discussions}

Hourly energy simulation has been performed for the building specified in Table 1 over all the five climatic zones of India as described in Table 4. The schedules for the simulation are as described in Table 2. In almost all the climatic zones, it is observed that the building needs to be cooled except in case of composite and cold climates where heating becomes essential. Therefore, both the cooling energy consumption and heating energy consumption of the building have been analysed to understand the merits and demerits of increasing the roof albedo. The total HVAC energy consumption (Cooling energy + Heating energy) of the building has been considered with the base case (without insulation) and accordingly the savings have been calculated. IRR has been computed for all cases considered at $5 \mathrm{~mm}$ incremental insulation thickness, SR of 0.6, and radiant barrier emissivity of 0.2

Though in this study, $5 \mathrm{~mm}$ incremental insulation has been considered, the commercial availability of insulation is limited to few thicknesses ( $25 \mathrm{~mm}, 30 \mathrm{~mm}, 40 \mathrm{~mm}, 50 \mathrm{~mm})$. For cases where the optimal insulation thickness is less than $25 \mathrm{~mm}\left(\mathrm{R}-\mathrm{V}\right.$ alue $\left.1.02 \mathrm{~m}^{2}-\mathrm{K} / \mathrm{W}\right)$, solutions have been suggested to improve the total roof insulation to reach the optimal Rvalue.

In case of the hot \& dry, temperate, and warm \& humid conditions the HVAC energy consumption consists only of cooling energy consumption. In case of composite and cold 
climate, there is a penalty from heating period. The HVAC energy consumption is a total of cooling energy and heating energy.

\subsection{HVAC Energy Consumption under Different Climatic Conditions}

The results obtained from simulation of different conditions as described above have been summarized and presented below for ready reference.

\subsubsection{Hot \& Dry Conditions}

Results show that for roofs with low solar reflectance, increase in insulation results in decrease in the cooling energy consumption. In case of hot $\&$ dry climate, point of inflexion occurs at $20 \mathrm{~mm}\left(\mathrm{R}-\mathrm{V}\right.$ alue $\left.0.85 \mathrm{~m}^{2}-\mathrm{K} / \mathrm{W}\right)$ of insulation for a roof with reflectivity of 0.7 . For higher values of roof reflectivity (SR $0.8,0.9$ ), addition of even $5 \mathrm{~mm}$ of insulation, results in negative savings. The IRR computed for insulation thickness beyond $10 \mathrm{~mm}$ ( $\mathrm{R}$ Value of 0.49 $\mathrm{m}^{2} \mathrm{~K} / \mathrm{W}$ ) indicate that the incremental benefit ceases and it will not be economically beneficial beyond this thickness. However, this thickness is less than the commercially available insulation solutions and hence, the use of an extra layer of brick bat coba is recommended for this climatic condition.

Brick bat coba is made of fully burnt brick pieces whose size ranges from 20 to $50 \mathrm{~mm}$ thickness. These are placed over the screed bed by hand packing with a minimum $15 \mathrm{~mm}$ thick mortar below the brick bats and suitable gaps in between, which are filled with a cement mortar ratio of 1:4.

Figure 3: Annual HVAC Energy Consumption - Ahmedabad (Hot \& Dry)

\subsubsection{Temperate Climatic Conditions}

In case of temperate climate, the point of inflexion is occurring at $30 \mathrm{~mm}\left(\mathrm{R}-\mathrm{V}\right.$ alue $1.20 \mathrm{~m}^{2}$ $\mathrm{K} / \mathrm{W}$ ) of roof insulation for a roof reflectivity of 0.5 . With increase in roof reflectivity, the point of inflexion moves further up and occurred at $5 \mathrm{~mm}$ for SR of 0.6 and less than $5 \mathrm{~mm}$ for $\mathrm{SR}>$ 0.7. IRR analysis shows that an insulation thickness beyond $5 \mathrm{~mm}$ (R-Value 0.31 $\mathrm{m}^{2}-\mathrm{K} / \mathrm{W}$ ) results in a net loss. Since the energy savings from using $5 \mathrm{~mm}$ of insulation is 1.03 $\mathrm{kWh} / \mathrm{m}^{2}$, and the IRR is only $20 \%$, improving the R-value of the roof would be beneficial.

Figure 4: Annual HVAC Energy Consumption - Banglaore (Temperate)

\subsubsection{Warm \& Humid Climatic Conditions}

In case of warm \& humid climate, for a roof reflectivity of 0.6 , the point of inflexion occurred at $20 \mathrm{~mm}\left(\mathrm{R}-\mathrm{V}\right.$ alue $\left.0.85 \mathrm{~m}^{2}-\mathrm{K} / \mathrm{W}\right)$. IRR analysis shows that beyond $5 \mathrm{~mm}$ (R-Value 
$\left.0.31 \mathrm{~m}^{2}-\mathrm{K} / \mathrm{W}\right)$ analysis, there is no financial benefit in adding more insulation. The energy savings achieved by using $5 \mathrm{~mm}$ insulation is $2.01 \mathrm{kWh} / \mathrm{m}^{2}$, which leads to an IRR of $36 \%$. Similar to the hot \& dry climatic conditions, using an additional layer such as Brick Bat Coba would help in optimizing the energy performance of the building.

Figure 5: Annual HVAC Energy Consumption - Mumbai (Warm \& Humid)

\subsubsection{Composite Climatic Conditions}

In case of composite climate, there is considerable amount of heating in the building. Though increased roof reflectivity results in heat penalty, the savings from the cooling period results in considerable overall savings. For a roof reflectivity of 0.6, the point of inflexion occurs at $35 \mathrm{~mm}$ for cooling energy consumption. Adding insulation beyond $25 \mathrm{~mm}$ (R-Value $1.02 \mathrm{~m}^{2}$ $\mathrm{K} / \mathrm{W}$ ) doesn't result in any saving in heating energy consumption. When cooling and heating energy consumptions are combined, it can be seen that adding insulation beyond $10 \mathrm{~mm}$ (RValue $0.49 \mathrm{~m}^{2}-\mathrm{K} / \mathrm{W}$ ) is not beneficial from IRR analysis. Similar to the hot \& dry climatic conditions, using Brick Bat Coba would help in increasing the energy performance of the roof.

Figure 6: Annual Cooling Energy Consumption - New Delhi (Composite)

Figure 7: Annual Heating Energy Consumption - New Delhi (Composite)

Figure 8: Annual HVAC Energy Consumption - New Delhi (Composite)

\subsubsection{Cold Climatic Conditions}

In case of cold climate, the point of inflexion occurs at less than $5 \mathrm{~mm}\left(\mathrm{R}-\right.$ Value $0.49 \mathrm{~m}^{2}-$ $\mathrm{K} / \mathrm{W}$ ) for a roof reflectivity of 0.6. Since the number of cooling degree days is very less, a cool roof with reflectivity of 0.6 can still be used. In case of heating energy consumption, heating energy reduces as insulation is added. The incremental saving reduces with increased insulation. IRR for total HVAC energy consumption shows that an insulation level beyond 25 $\mathrm{mm}$ (R-Value $\left.1.02 \mathrm{~m}^{2}-\mathrm{K} / \mathrm{W}\right)$ results in negative financial benefits. Hence, commercially available insulation of $25 \mathrm{~mm}$ can be used, which will result in financial benefits.

Figure 9: Annual Cooling Energy Consumption - Shillong (Cold)

Figure 10: Annual Heating Energy Consumption - Shillong (Cold)

Figure 11: Annual HVAC Energy Consumption - Shillong (Cold)

Table 5: Annual incremental savings of HVAC energy consumption and IRR for a roof with Cool Roof reflectivity of 0.4 , and Radiant Barrier thermal emissivity of 0.2 for five different climatic zones in India

Table 5: Annual incremental savings of HVAC energy consumption and IRR for a roof with Cool Roof reflectivity of 0.6, and Radiant Barrier thermal emissivity of 0.2 for five different climatic zones in India 


\section{Conclusion}

By using Cool Roofs and Radiant Barriers, the need for insulation reduces in a building in all five climatic zones of India. Using IRR analysis, it is found that the incremental benefits from additional insulation ceases for less than the commercially available insulation for all climates except cold climates. For hot \& dry, and composite climates, the financial benefit ceases at a combined roof R-value of $0.49 \mathrm{~m}^{2}-\mathrm{K} / \mathrm{W}$ and for warm \& humid, and temperate climate, the financial benefit ceases at a combined roof value of $0.31 \mathrm{~m}^{2}-\mathrm{K} / \mathrm{W}$. This can be achieved by using an additional layer such as Brick Bat Coba over the roof. In case of cold climates, due to the heating penalty in the winter months, insulation is required. It is observed that insulation beyond $25 \mathrm{~mm}\left(1.02 \mathrm{~m}^{2}-\mathrm{K} / \mathrm{W}\right)$ does not yield financial benefits. Therefore, the least available commercial insulation should be sufficient for cold climates, when the roof has Radiant Barrier and cool roofs.

\section{Acknowledgement}

This work was partially supported by Joint Clean Energy Research and Development Centre (JCERDC) for buildings called Centre for Building Energy Research and Development (CBERD) funded by the Indian Ministry of Science \& Technology, and U.S. Department of Energy and administered by Indo-US Science and Technology Forum in India.

\section{References:}

1. Solanki, C. S. (2010). Solar PV Electricity SolutionsforAcademic Campuses in India. Indian Institute of Technology - Bombay.

2. Takebayashi. (2009). Daily Net Solar Radiation gain in summer on each surface of the isolated building. Building and Energy.

3. Cool Roof Rating Council: Resources. (2013, 03 15). Retrieved 03 15, 2013, from Cool Roof Rating Council: http://coolroofs.org/HomeandBuildingOwnersInfo.html

4. Mario A Medina, P. P. (2010). A Comprehensive Review of Radiant Barrier Research Including Laboratory and Field Experiments. ASHRAE.

5. ASTM C1313. (2013). ASTM Volume 04.06 Thermal Insulation; Building and Environmental Acoustics. 
6. D'Orazio, M., Di Perna, C., \& Di Giuseppe, E. (2010, October). The effects of roof covering on the thermal performance of highly insulated roofs in Mediterranean climates. Energy and Buildings, 42(10).

7. Halwatura, R., \& Jayasinghe, M. (2009, June). Influence of insulated roof slabs on air conditioned spaces in tropical climatic conditions - A life cycle approach. Energy and Buildings, 41(6), 678-686.

8. Masoso, O., \& Grobler, L. (2008). A new and innovative look at anti-insulation behaviour in building energy consumption. Energy and Buildings, 40(10), 1889-1894.

9. Lollini, Barozzi, Fasano, Meroni, \& Zinizi. (2006, August). Optimisation of opaque components of the building envelope. Energy, economic and environmental issues. Building and Environment, 41(8), 1001-1013.

10. Akhbari, H., Konopacki, S., \& Parker, D. (1998). Updates on Revision to ASHRAE Standard 90.2: Including Roof reflectivity for Residenttial Buildings. ASHRAE Transactions.

11. Akbari, H., Konopacki, S., Parker , D., Wilcox, B., Eley, C., \& Geem, V. M. (1998). Calculations in support of SSP 90.1 for reflective roofs. ASHRAE Transactions, 984995.

12. Gentle , A., Aguliar, J., \& Smith, G. (2011, December). Optimized cool roofs: Integrating albedo and thermal emittance with R-value. Solar Energy Materials and Solar Cells, 3207-3215.

13. Bureau of Indian Standards. (2005). National Building Code of India.

14. Greer, E. G., \& Kolbe, T. P. (2003). Investment Analysis for Real Estate Decisions. Dearborn Real Estate Education.

15. Planning Commision Government of India (Power \& Energy Division). (n.d.) Reports. Retrieved 03 29, 2013, from Planning Commision Government of India: http://planningcommission.nic.in/reports/genrep/arep_seb11_12.pdf

16. Indian Banks' Association. (n.d.). Wholesale Banking - Benchmark PLR. Retrieved 03 29, 2013, from http://www.iba.org.in/viewplr.asp?memcatid=1 
Table 1: Input details of the simulation model

\begin{tabular}{|c|c|}
\hline \multicolumn{2}{|c|}{ General Information } \\
\hline Building type & Office \\
\hline Location & 5 different climates as per National Building Code \\
\hline Geometry & $14.14 \mathrm{~m} \mathrm{X} 14.14 \mathrm{~m}$ \\
\hline Number of zones & 5 ( 4 perimeter +1 core $)$ \\
\hline Floor area & $200 \mathrm{~m}^{2}$ \\
\hline \multicolumn{2}{|c|}{ Activity \& Internal Loads } \\
\hline Occupancy & From 9:00 - 17:00 \\
\hline Zone Floor Area per Person & $14 \mathrm{~m}^{2} /$ person \\
\hline Lighting Power Density & $10.8 \mathrm{~W} / \mathrm{m}^{2}$ \\
\hline Electric Power Density & $16.15 \mathrm{~W} / \mathrm{m}^{2}$ \\
\hline Infiltration & $\begin{array}{c}\text { Core zone }-0.1 \mathrm{ACH} \\
\text { Perimeter zone }-0.2 \mathrm{ACH}\end{array}$ \\
\hline \multicolumn{2}{|c|}{ Construction } \\
\hline Wall U - Value & $0.44 \mathrm{~W} / \mathrm{m}^{2} \mathrm{~K}$ \\
\hline \multicolumn{2}{|c|}{ Openings } \\
\hline U value of fenestration & $3.3 \mathrm{~W} / \mathrm{m}^{2} \mathrm{~K}$ \\
\hline SHGC & 0.25 \\
\hline Light transmission & 0.2 \\
\hline \multicolumn{2}{|c|}{ HVAC } \\
\hline HVAC system type & PTAC \\
\hline Heating CoP & 1.0 (Electrical) \\
\hline Cooling CoP & 3.0 (Electrical) \\
\hline Heating set point & $20^{\circ} \mathrm{C}$ \\
\hline Cooling set point & $25^{\circ} \mathrm{C}$ \\
\hline Heating set back & $10^{\circ} \mathrm{C}$ \\
\hline Cooling set back & $40^{\circ} \mathrm{C}$ \\
\hline
\end{tabular}


Table 2: Schedules considered for the simulation model

\begin{tabular}{|c|c|c|c|c|c|}
\hline \multicolumn{6}{|c|}{ Daytime operation } \\
\hline $\begin{array}{l}\text { Schedule } \\
\text { Name }\end{array}$ & Schedule Type & Day Type & $\begin{array}{ll}\text { 00:00 } & - \\
\text { 09:00 } & \end{array}$ & $\begin{array}{l}\text { 09:00 - } \\
17: 00\end{array}$ & $\begin{array}{l}17: 00 \\
24: 00\end{array}$ \\
\hline \multirow{2}{*}{ Occupancy } & \multirow{2}{*}{$\begin{array}{l}\text { Fraction of design value } \\
\text { (14 person approx.) }\end{array}$} & Weekday & 0 & 1 & 0 \\
\hline & & Weekend & 0 & 0 & 0 \\
\hline \multirow{2}{*}{ Lighting } & \multirow{2}{*}{$\begin{array}{l}\text { Fraction of design value } \\
\left(10.8 \mathrm{w} / \mathrm{m}^{2}\right)\end{array}$} & Weekday & 0.05 & 1 & 0.05 \\
\hline & & Weekend & 0.05 & 0.05 & 0.05 \\
\hline \multirow{2}{*}{ Equipment } & \multirow{2}{*}{$\begin{array}{l}\text { Fraction of design value } \\
\left(16.15 \mathrm{w} / \mathrm{m}^{2}\right)\end{array}$} & Weekday & 0.05 & 1 & 0.05 \\
\hline & & Weekend & 0.05 & 0.05 & 0.05 \\
\hline \multirow{2}{*}{$\begin{array}{l}\text { Cooling } \\
\text { set point }\end{array}$} & \multirow{2}{*}{$\begin{array}{l}\text { Temperature } \\
\text { (set point temperature) }\end{array}$} & Weekday & 40 & 25 & 40 \\
\hline & & Weekend & 40 & 40 & 40 \\
\hline \multirow{2}{*}{$\begin{array}{l}\text { Heating set } \\
\text { point }\end{array}$} & \multirow{2}{*}{$\begin{array}{l}\text { Temperature } \\
\text { (set point temperature) }\end{array}$} & Weekday & 10 & 20 & 10 \\
\hline & & Weekend & 10 & 10 & 10 \\
\hline \multirow{2}{*}{ HVAC } & \multirow{2}{*}{ On/Off } & Weekday & 0 & 1 & 0 \\
\hline & & Weekend & 0 & 0 & 0 \\
\hline \multirow{2}{*}{ Infiltration } & \multirow{2}{*}{ Fraction } & Weekday & 1 & 0 & 1 \\
\hline & & Weekend & 1 & 1 & 1 \\
\hline
\end{tabular}

Table 3: Roof material properties

\begin{tabular}{|l|c|c|c|}
\hline & Roof Insulation & Cool Roof & Radiant Barriers \\
\hline $\begin{array}{l}\text { Thermal Conductivity } \\
(\mathrm{W} / \mathrm{m}-\mathrm{K})\end{array}$ & 0.028 & 0.88 & 0.88 \\
\hline Density $\left(\mathrm{kg} / \mathrm{m}^{3}\right)$ & 32 & - & - \\
\hline
\end{tabular}




\begin{tabular}{|l|c|c|c|}
\hline Specific Heat $(\mathrm{J} / \mathrm{kg}-\mathrm{K})$ & 1400 & 896 & 896 \\
\hline Thickness $(\mathrm{m})$ & $0.005-0.05$ & 0.005 & 0.005 \\
\hline Solar Reflectivity & 0.3 & $0.2-0.9$ & 0.3 \\
\hline Thermal Emissivity & 0.9 & 0.9 & 0.2 \\
\hline
\end{tabular}

Table 4: Cities chosen for simulation study

\begin{tabular}{|c|c|c|c|c|c|c|c|c|}
\hline City & $\begin{array}{l}\text { Climatic } \\
\text { zone }\end{array}$ & Latitude & Longitude & $\begin{array}{l}\text { HDD } \\
\left(18^{0} \mathrm{C}\right)\end{array}$ & $\begin{array}{l}\mathrm{CDD} \\
\left(18^{0} \mathrm{C}\right)\end{array}$ & $\begin{array}{c}\text { Maximum } \\
\text { Daily Direct } \\
\text { Normal } \\
\text { Solar } \\
\text { Radiation } \\
\left(\mathrm{Wh} / \mathrm{m}^{2}\right)\end{array}$ & $\begin{array}{c}\text { Maximum } \\
\text { Daily Direct } \\
\text { Global } \\
\text { Horizontal } \\
\text { Radiation } \\
\left(\mathrm{Wh} / \mathrm{m}^{2}\right)\end{array}$ & Weather file used \\
\hline Ahmedabad & Hot \& Dry & $\mathrm{N} 23^{0} 4^{\prime}$ & E $72^{0} 37^{\prime}$ & 13 & 3381 & 7429 & 5548 & $\begin{array}{l}\text { IND_Ahmedabad. } \\
\text { 426470_ISHRAE }\end{array}$ \\
\hline Mumbai & $\begin{array}{l}\text { Warm \& } \\
\text { Humid }\end{array}$ & $\mathrm{N} 19^{0} 7^{\prime}$ & E $72^{0} 50^{\prime}$ & 0 & 3300 & 7062 & 5017 & $\begin{array}{l}\text { IND_Mumbai. } \\
\text { 430030_ISHRAE }\end{array}$ \\
\hline New Delhi & Composite & N 28 $34^{\prime}$ & $\mathrm{E} 77^{0} 11^{\prime}$ & 321 & 2680 & 7196 & 5366 & $\begin{array}{l}\text { IND_New.Delhi. } \\
\text { 421820_ISHRAE }\end{array}$ \\
\hline Bangalore & Temperate & $\mathrm{N} 12^{0} 58^{\prime}$ & E $77^{0} 34^{\prime}$ & 0 & 2036 & 8450 & 5244 & $\begin{array}{l}\text { IND_Bangalore. } \\
\text { 432950_ISHRAE }\end{array}$ \\
\hline Shillong & Cold & $\mathrm{N} 25^{0} 24^{\prime}$ & E $91^{0} 52^{\prime}$ & 1454 & 121 & 7967 & 3836 & $\begin{array}{l}\text { IND_Shillong. } \\
\text { 425160_ISHRAE }\end{array}$ \\
\hline
\end{tabular}


Table 5: Annual incremental savings of HVAC energy consumption and IRR for a roof with Cool Roof reflectivity of 0.4, and Radiant Barrier thermal emissivity of 0.2 for five different climatic zones in India

\begin{tabular}{|c|c|c|c|c|c|c|c|c|c|c|c|c|c|}
\hline \multirow[t]{2}{*}{$\begin{array}{c}\text { Insulation } \\
\text { Thickness } \\
\text { (mm) }\end{array}$} & \multirow[t]{2}{*}{$\begin{array}{c}\text { Insulation } \\
\text { R value } \\
\left(\mathrm{m}^{2} \mathrm{~K} / \mathrm{W}\right)\end{array}$} & \multirow[t]{2}{*}{$\begin{array}{c}\text { Cost of } \\
\text { Insulation } \\
\left(\mathrm{INR} / \mathrm{m}^{2}\right)\end{array}$} & \multirow{2}{*}{$\begin{array}{l}\text { Cost of } \\
\text { Incremental } \\
\text { Insulation } \\
(\text { INR/m²) }\end{array}$} & \multicolumn{2}{|c|}{$\begin{array}{c}\text { Hot \& Dry } \\
\text { (Ahmedabad) }\end{array}$} & \multicolumn{2}{|c|}{$\begin{array}{l}\text { Temperate } \\
\text { (Bangalore) }\end{array}$} & \multicolumn{2}{|c|}{$\begin{array}{l}\text { Warm and Humid } \\
\text { (Mumbai) }\end{array}$} & \multicolumn{2}{|c|}{$\begin{array}{c}\text { Composite (New } \\
\text { Delhi) }\end{array}$} & \multicolumn{2}{|c|}{ Cold (Shillong) } \\
\hline & & & & $\begin{array}{l}\text { Savings } \\
\left(\mathrm{kWh} / \mathrm{m}^{2}\right)\end{array}$ & IRR & $\begin{array}{l}\text { Savings } \\
\left(\mathrm{kWh} / \mathrm{m}^{2}\right)\end{array}$ & IRR & $\begin{array}{l}\text { Savings } \\
\left(\mathrm{kWh} / \mathrm{m}^{2}\right)\end{array}$ & IRR & $\begin{array}{l}\text { Savings } \\
\left(\mathrm{kWh} / \mathrm{m}^{2}\right)\end{array}$ & IRR & $\begin{array}{l}\text { Savings } \\
\left(\mathrm{kWh} / \mathrm{m}^{2}\right)\end{array}$ & IRR \\
\hline 5 & 0.31 & 40 & 40 & 6.05 & $98.15 \%$ & 3.76 & $63.21 \%$ & 4.39 & $72.85 \%$ & 5.25 & $85.97 \%$ & 1.74 & $32.05 \%$ \\
\hline 10 & 0.49 & 80 & 40 & 2.37 & $41.85 \%$ & 1.29 & $24.90 \%$ & 1.68 & $31.11 \%$ & 2.11 & $37.82 \%$ & 1.4 & $26.67 \%$ \\
\hline 15 & 0.67 & 120 & 40 & 1.68 & $31.11 \%$ & 0.59 & $12.67 \%$ & 0.66 & $14.04 \%$ & 1.35 & $25.87 \%$ & 1.04 & $20.78 \%$ \\
\hline 20 & 0.85 & 160 & 40 & 1 & $20.11 \%$ & 0.35 & $7.30 \%$ & 0.49 & $10.59 \%$ & 0.59 & $12.67 \%$ & 0.72 & $15.17 \%$ \\
\hline 25 & 1.02 & 200 & 40 & 0.74 & $15.54 \%$ & 0.23 & $3.83 \%$ & 0.36 & $7.56 \%$ & 0.58 & $12.47 \%$ & 0.49 & $10.59 \%$ \\
\hline 30 & 1.2 & 240 & 40 & 0.59 & $12.67 \%$ & 0.16 & $1.22 \%$ & 0.45 & $9.70 \%$ & 0.36 & $7.56 \%$ & 0.3 & $5.96 \%$ \\
\hline 35 & 1.38 & 280 & 40 & 0.46 & $9.93 \%$ & 0.14 & $0.33 \%$ & -2.78 & $0.00 \%$ & 0.29 & $5.67 \%$ & 0.25 & $4.47 \%$ \\
\hline 40 & 1.56 & 320 & 40 & 0.38 & $8.05 \%$ & 0.1 & $0.00 \%$ & 3.17 & $0.00 \%$ & 0.23 & 3.83 & 0.11 & $0.00 \%$ \\
\hline 45 & 1.74 & 360 & 40 & 0.33 & $6.78 \%$ & 0.09 & $0.00 \%$ & 0.16 & $0.00 \%$ & 0.19 & $2.48 \%$ & 0.07 & $0.00 \%$ \\
\hline 50 & 1.92 & 400 & 40 & 0.27 & $5.08 \%$ & 3.07 & $0.00 \%$ & 0 & $0.00 \%$ & 0.15 & 0.78 & 0.06 & $0.00 \%$ \\
\hline
\end{tabular}

Table 5: Annual incremental savings of HVAC energy consumption and IRR for a roof with Cool Roof reflectivity of 0.6, and Radiant Barrier thermal emissivity of 0.2 for five different climatic zones in India

\begin{tabular}{|c|c|c|c|c|c|c|c|c|c|c|c|c|c|}
\hline \multirow[t]{2}{*}{$\begin{array}{c}\text { Insulation } \\
\text { Thickness } \\
\text { (mm) }\end{array}$} & \multirow[t]{2}{*}{$\begin{array}{c}\text { Insulation } \\
\mathrm{R} \text { value } \\
\left(\mathrm{m}^{2} \mathrm{~K} / \mathrm{W}\right)\end{array}$} & \multirow[t]{2}{*}{$\begin{array}{c}\text { Cost of } \\
\text { Insulation } \\
\left(\mathrm{INR} / \mathrm{m}^{2}\right)\end{array}$} & \multirow{2}{*}{$\begin{array}{c}\text { Cost of } \\
\text { Incremental } \\
\text { Insulation } \\
\left(\mathrm{INR} / \mathrm{m}^{2}\right)\end{array}$} & \multicolumn{2}{|c|}{$\begin{array}{c}\text { Hot \& Dry } \\
\text { (Ahmedabad) }\end{array}$} & \multicolumn{2}{|c|}{$\begin{array}{l}\text { Temperate } \\
\text { (Bangalore) }\end{array}$} & \multicolumn{2}{|c|}{$\begin{array}{l}\text { Warm and Humid } \\
\text { (Mumbai) }\end{array}$} & \multicolumn{2}{|c|}{$\begin{array}{c}\text { Composite (New } \\
\text { Delhi) }\end{array}$} & \multicolumn{2}{|c|}{ Cold (Shillong) } \\
\hline & & & & $\begin{array}{l}\text { Savings } \\
\left(\mathrm{kWh} / \mathrm{m}^{2}\right)\end{array}$ & IRR & $\begin{array}{l}\text { Savings } \\
\left(\mathrm{kWh} / \mathrm{m}^{2}\right)\end{array}$ & IRR & $\begin{array}{l}\text { Savings } \\
\left(\mathrm{kWh} / \mathrm{m}^{2}\right)\end{array}$ & IRR & $\begin{array}{l}\text { Savings } \\
\left(\mathrm{kWh} / \mathrm{m}^{2}\right)\end{array}$ & IRR & $\begin{array}{l}\text { Savings } \\
\left(\mathrm{kWh} / \mathrm{m}^{2}\right)\end{array}$ & IRR \\
\hline 5 & 0.31 & 40 & 40 & 2.91 & $50.90 \%$ & 1.03 & $20.69 \%$ & 2.01 & $36.67 \%$ & 2.90 & $50.75 \%$ & 3.07 & $53.40 \%$ \\
\hline
\end{tabular}




\begin{tabular}{|c|c|c|c|c|c|c|c|c|c|c|c|c|c|}
\hline 10 & 0.49 & 80 & 40 & 0.97 & $19.76 \%$ & $0.05^{-}$ & - & 0.10 & $-1.50 \%$ & 1.18 & $23.26 \%$ & 2.14 & $38.61 \%$ \\
\hline 15 & 0.67 & 120 & 40 & 0.52 & $11.32 \%$ & 0.22 & - & 0.14 & $0.38 \%$ & 0.38 & $7.96 \%$ & 1.49 & $28.27 \%$ \\
\hline 20 & 0.85 & 160 & 40 & 0.34 & $7.27 \%$ & $0.21^{-}$ & - & 0.01 & $-12.19 \%$ & 0.19 & $2.71 \%$ & 0.98 & $19.90 \%$ \\
\hline 25 & 1.02 & 200 & 40 & 0.26 & $4.75 \%$ & $0.19^{-}$ & - & -0.05 & - & 0.10 & $-2.08 \%$ & 0.65 & $13.98 \%$ \\
\hline 30 & 1.20 & 240 & 40 & 0.18 & $2.07 \%$ & $0.17^{-}$ & - & 0.13 & $-0.31 \%$ & 0.06 & $-4.79 \%$ & 0.43 & $9.22 \%$ \\
\hline 35 & 1.38 & 280 & 40 & 0.14 & $0.18 \%$ & $0.15^{-}$ & - & 0.00 & - & 0.01 & $-14.90 \%$ & 0.29 & $5.65 \%$ \\
\hline 40 & 1.56 & 320 & 40 & 0.12 & $-0.52 \%$ & $0.13^{-}$ & - & -0.06 & - & $0.00^{-}$ & - & 0.20 & $2.64 \%$ \\
\hline 45 & 1.74 & 360 & 40 & 0.09 & $-2.74 \%$ & $0.11^{-}$ & - & -0.03 & - & 0.00 & $-16.38 \%$ & 0.16 & $1.29 \%$ \\
\hline 50 & 1.92 & 400 & 40 & 0.13 & $-0.27 \%$ & $0.10^{-}$ & - & -0.03 & - & $0.01^{-}$ & - & 0.06 & $-4.88 \%$ \\
\hline
\end{tabular}




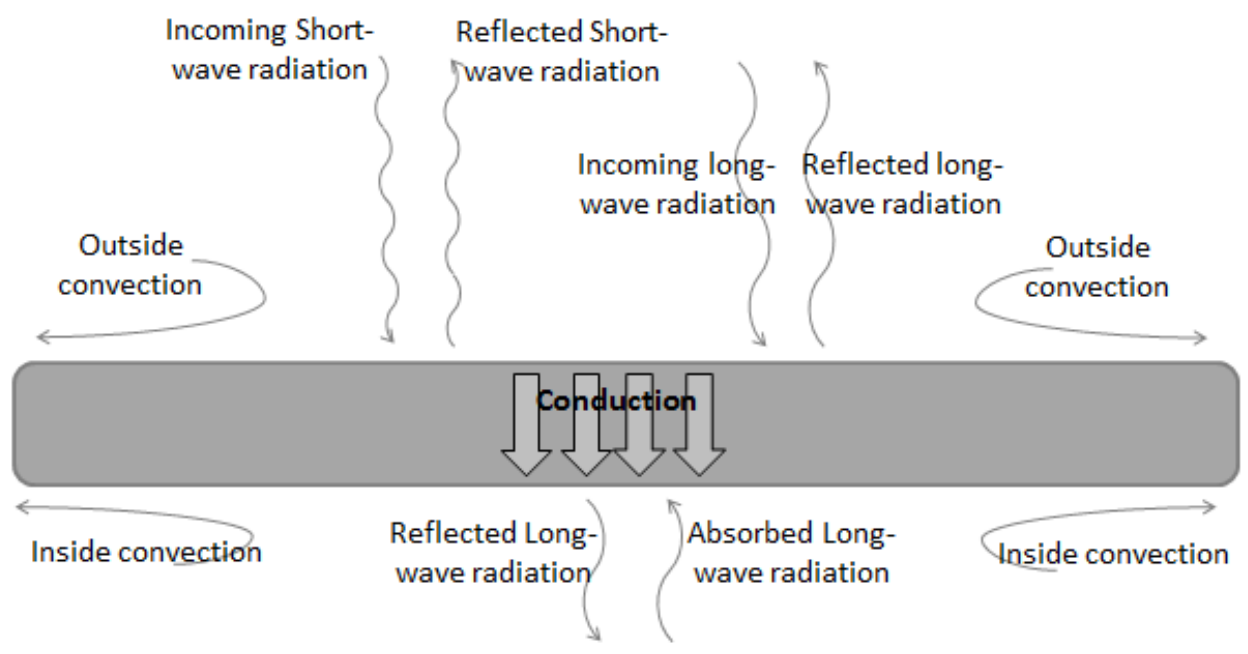

Figure 1: Heat transfer in a roof
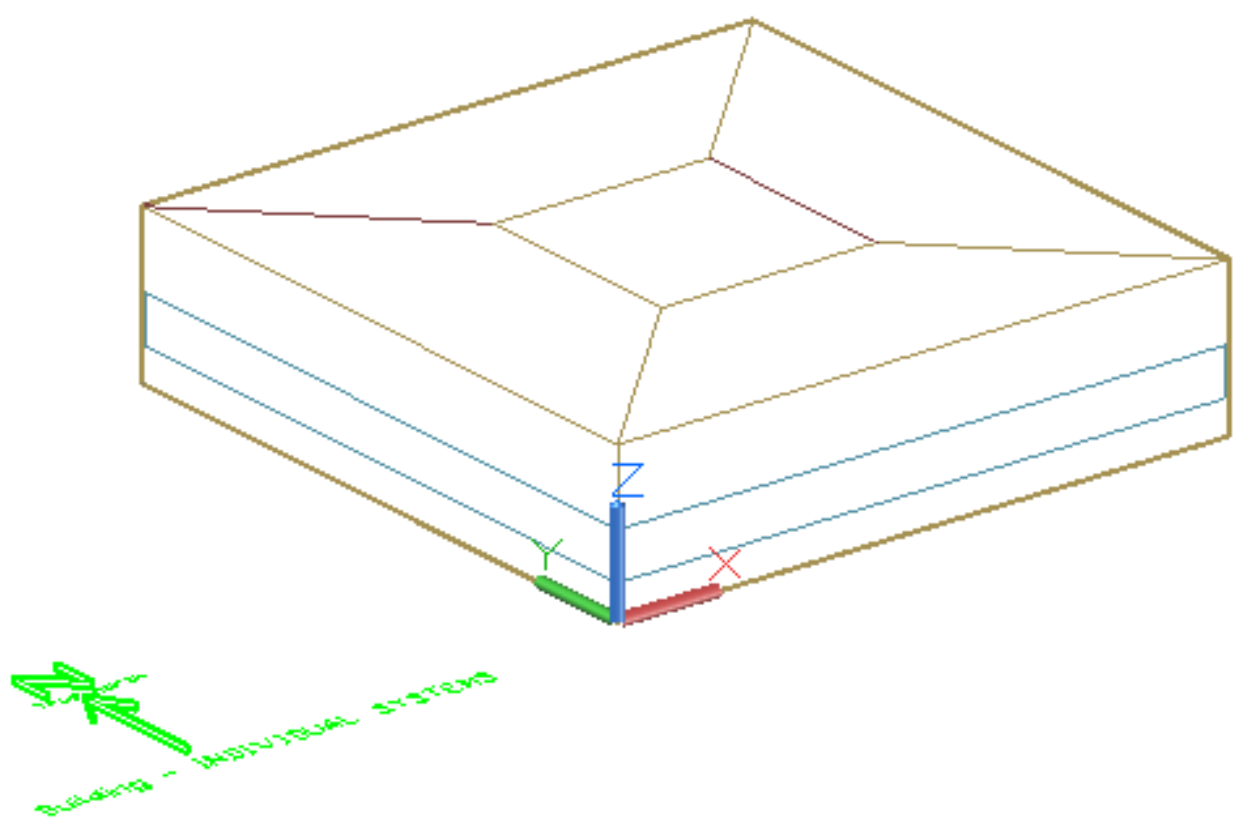

Figure 2: Schematic of the model considered for the simulation study 


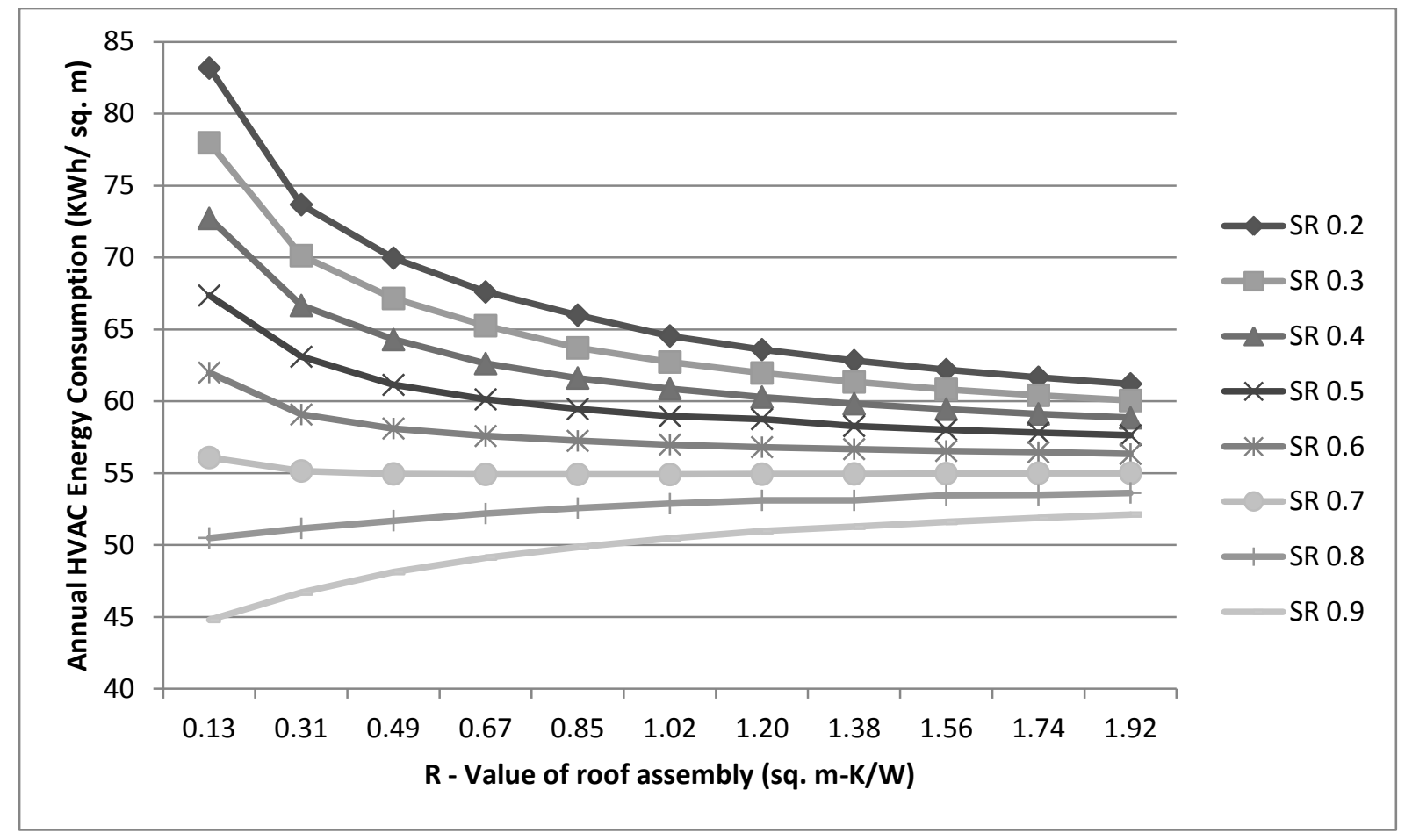

Figure 3: Annual HVAC Energy Consumption - Ahmedabad (Hot \& Dry)

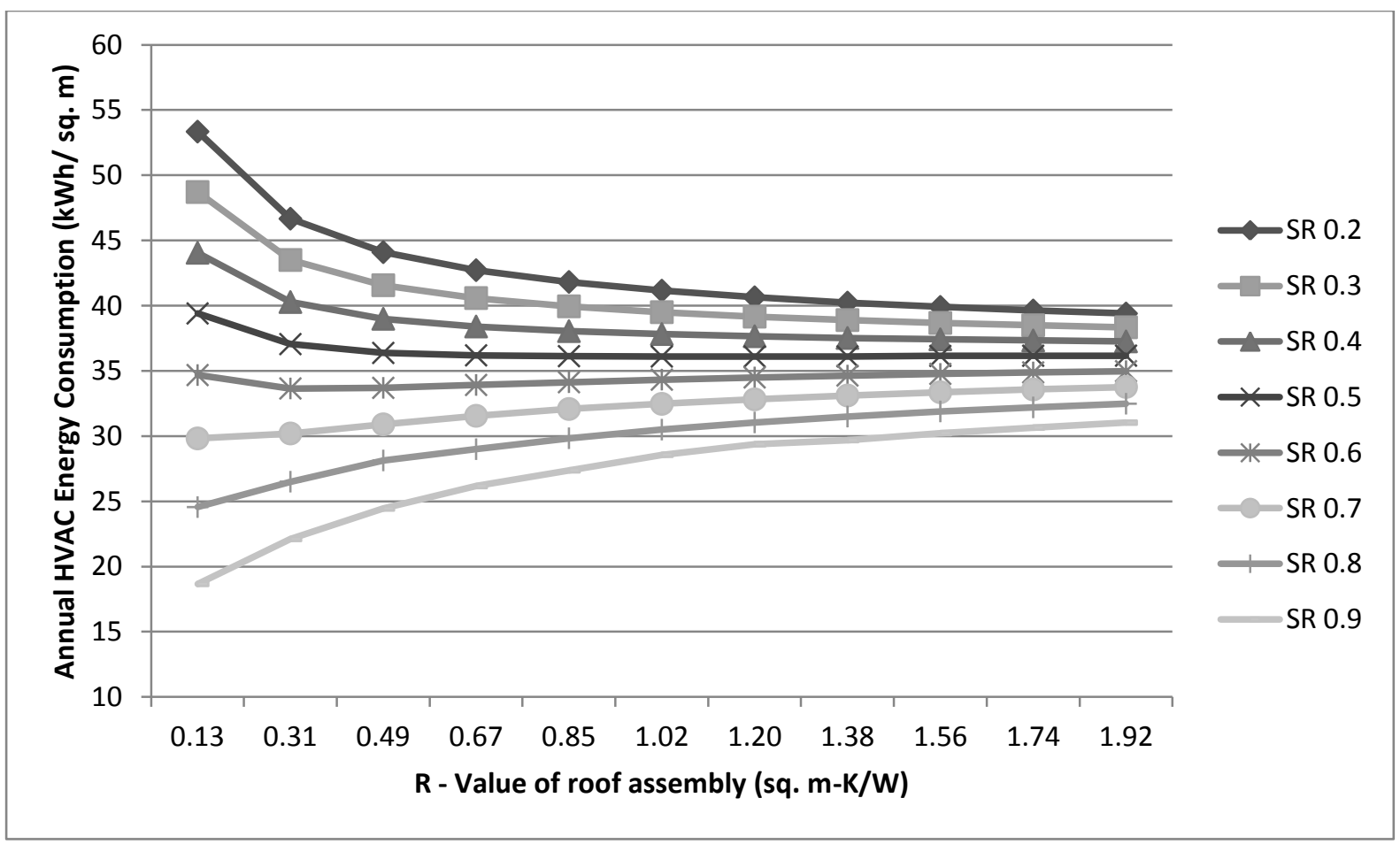

Figure 4: Annual HVAC Energy Consumption - Banglaore (Temperate) 


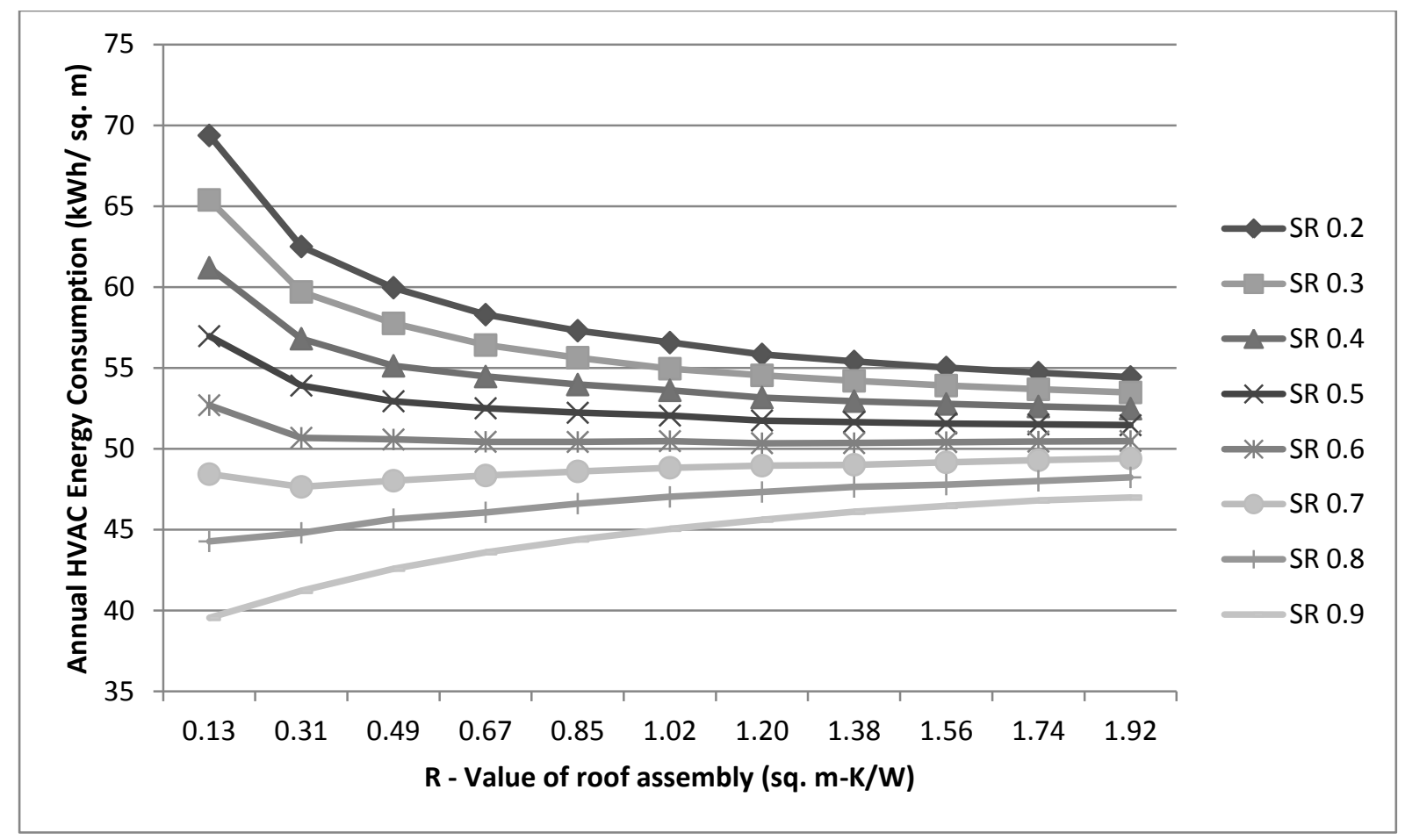

Figure 5: Annual HVAC Energy Consumption - Mumbai (Warm \& Humid)

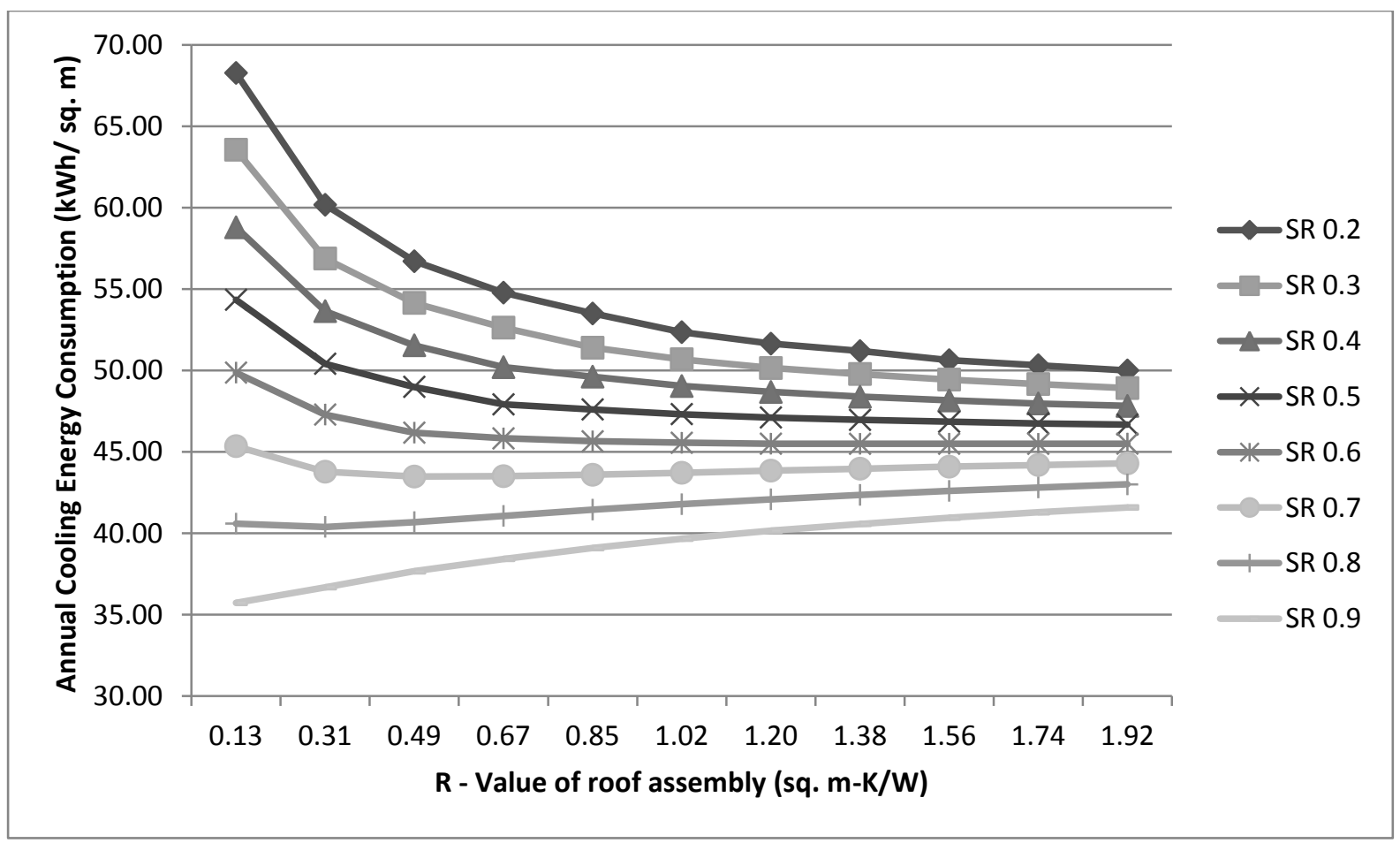

Figure 6: Annual Cooling Energy Consumption - New Delhi (Composite) 


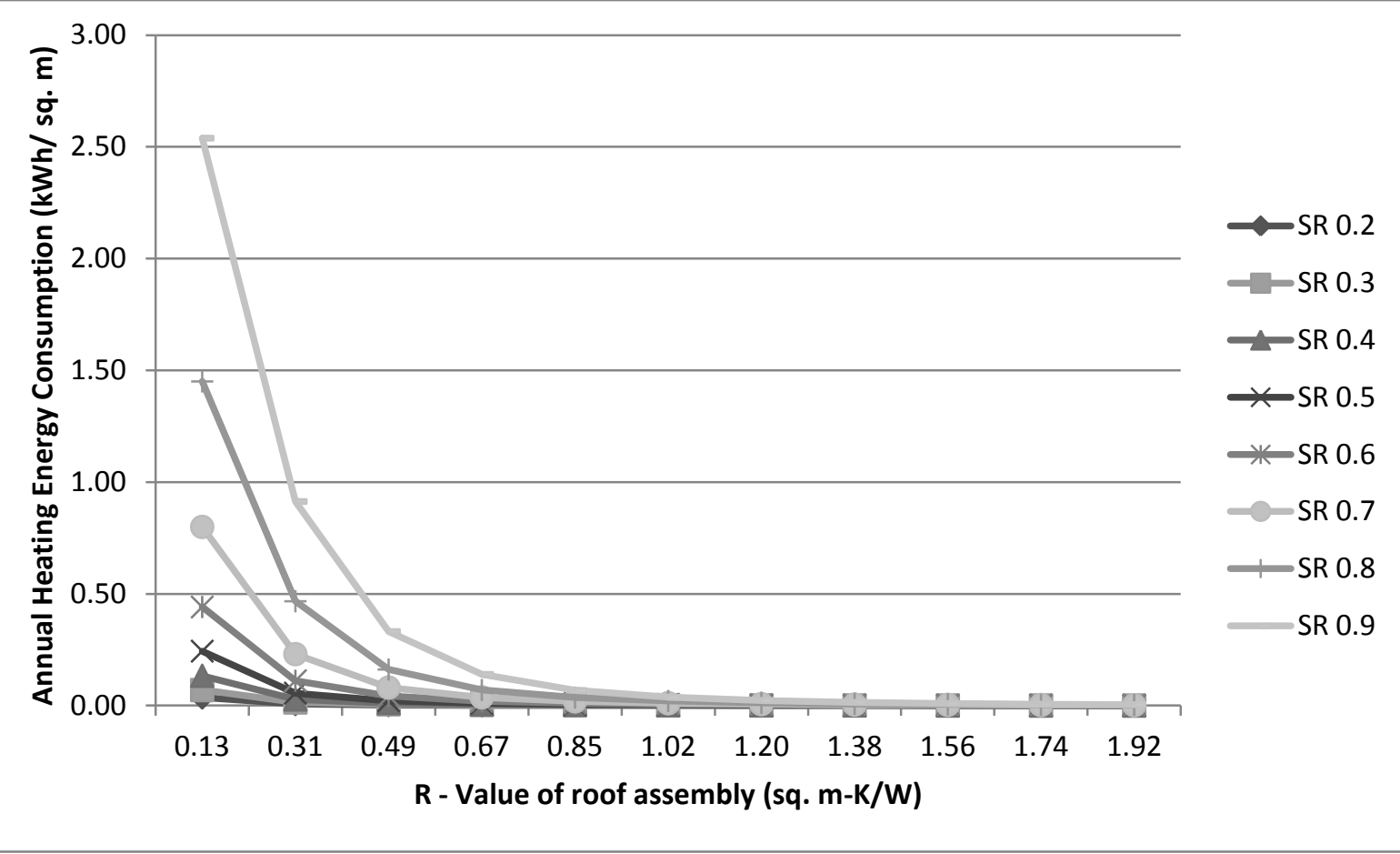

Figure 7: Annual Heating Energy Consumption - New Delhi (Composite)

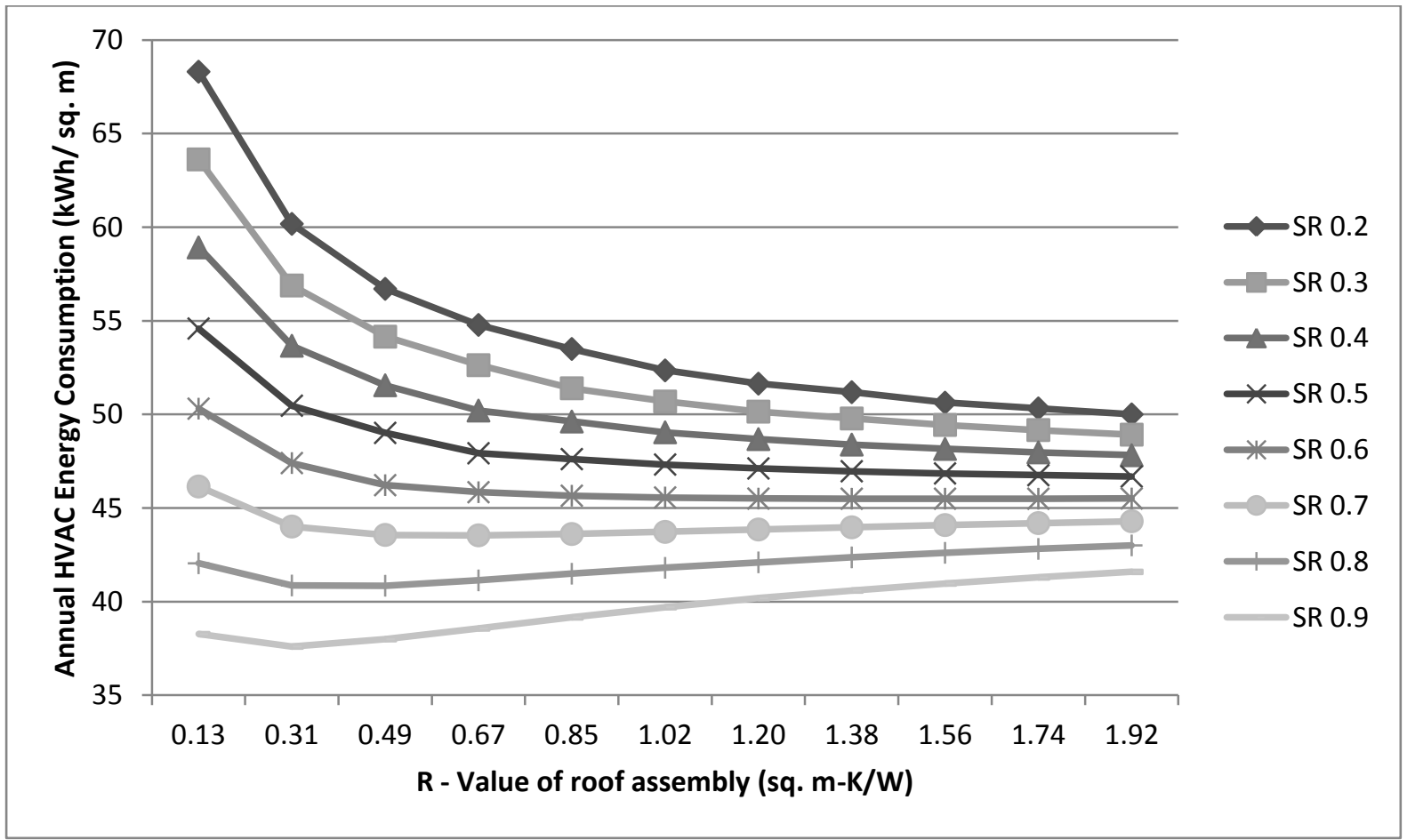

Figure 8: Annual HVAC Energy Consumption - New Delhi (Composite) 


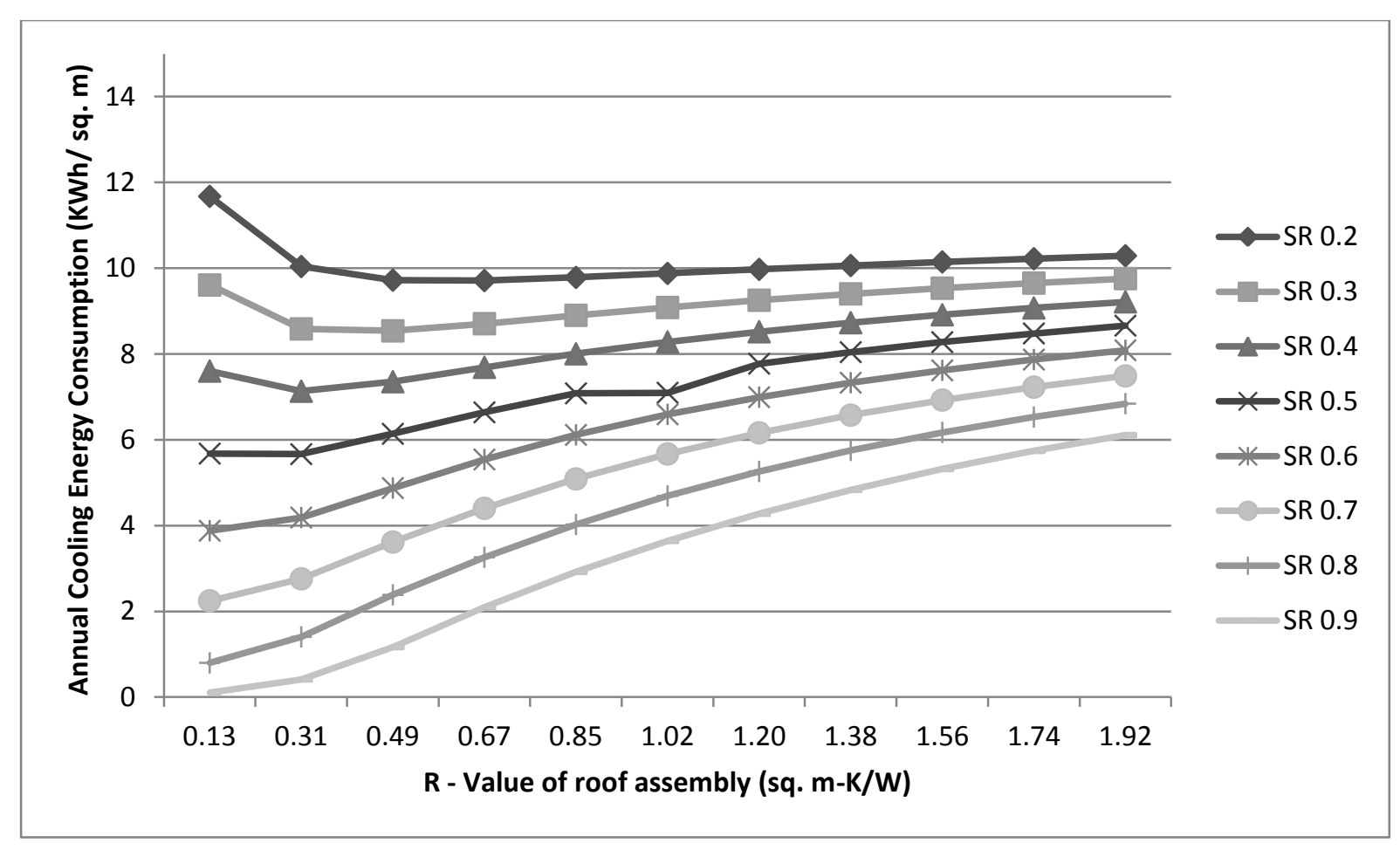

Figure 9: Annual Cooling Energy Consumption - Shillong (Cold)

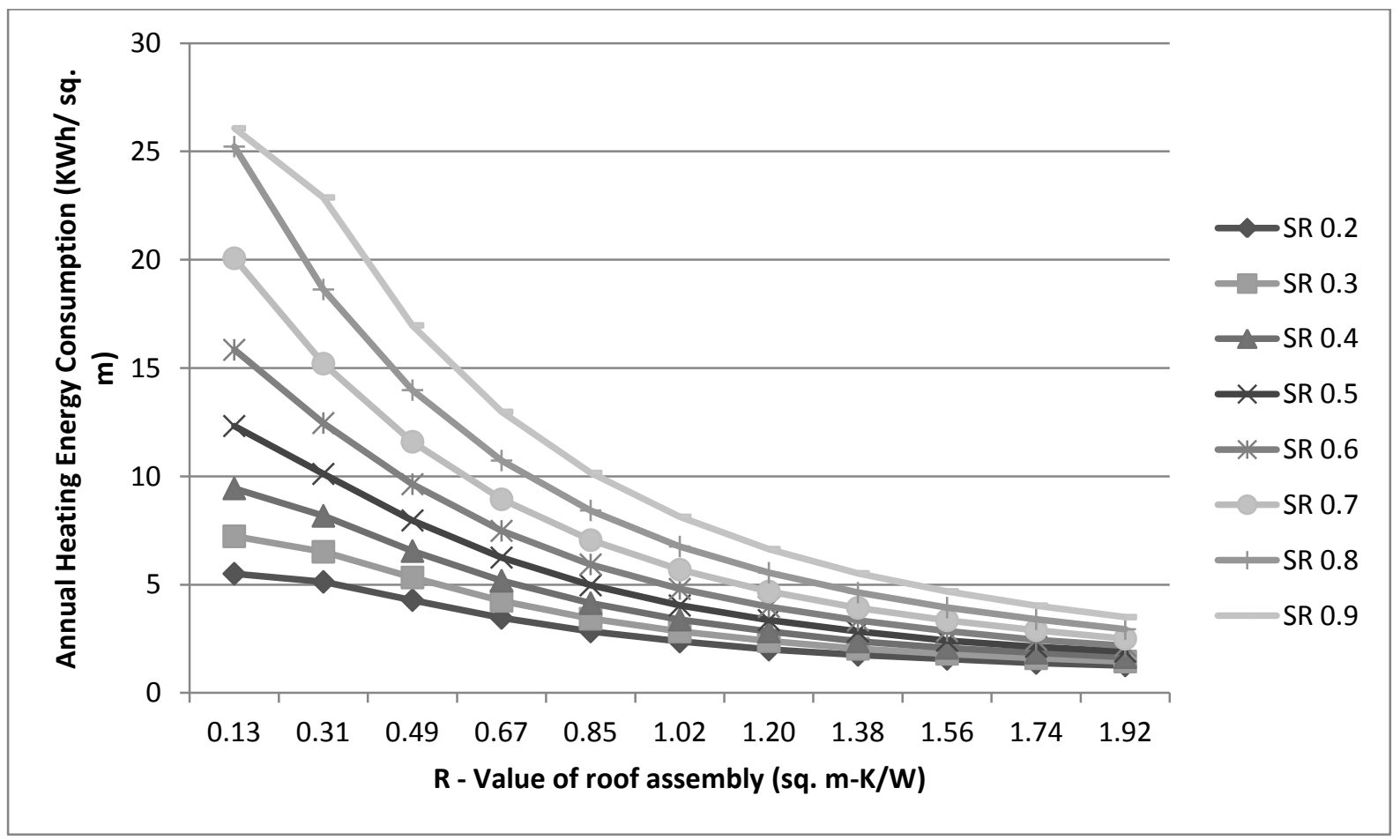

Figure 10: Annual Heating Energy Consumption - Shillong (Cold) 


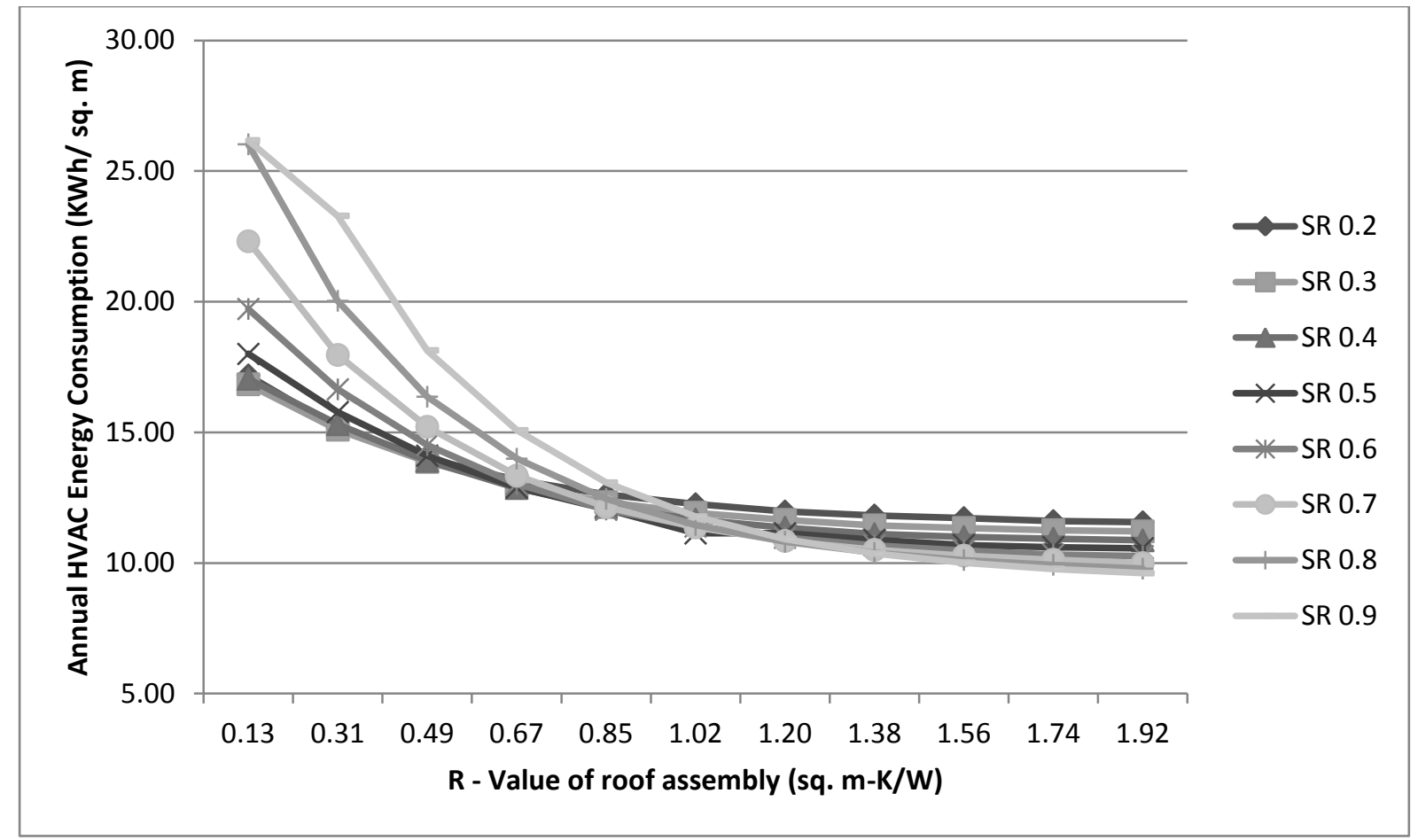

Figure 11: Annual HVAC Energy Consumption - Shillong (Cold) 